Article

\title{
Relative Salt Tolerance of Four Herbaceous Perennial Ornamentals
}

\author{
Triston Hooks and Genhua Niu *(D) \\ Texas A\&M AgriLife Research, El Paso, TX 79927, USA; triston.hooks@ag.tamu.edu \\ * Correspondence: gniu@ag.tamu.edu; Tel.: +1-915-859-9111
}

Received: 26 March 2019; Accepted: 8 May 2019; Published: 11 May 2019

\begin{abstract}
Salt tolerant ornamental plants can be irrigated with alternative water sources that are typically saline as a sustainable practice for urban landscaping, especially in arid and semi-arid regions. However, the salt tolerance of many ornamentals is not known. An eight-week greenhouse experiment was conducted to assess the relative salt tolerance of four perennial ornamentals, 'Angelina' (Sedum rupestre), 'Autumn Joy' (S. telephium), 'Blue Spruce' (S. reflexum), and 'Blue Daze' (Evolvulus glomeratus). The plants were grown in pots with potting mix substrate and irrigated with control or saline solutions. The electrical conductivities (EC) of the saline solutions were 5.0 and $10.0 \mathrm{mS} / \mathrm{cm}$. Data collected included relative shoot, root, and total dry weight (DW), visual score, shoot tissue concentrations of $\mathrm{Na}^{+}, \mathrm{Cl}^{-}, \mathrm{K}^{+}$, and $\mathrm{Ca}^{2+}$, and the $\mathrm{K}^{+} / \mathrm{Na}^{+}$ratio. There were significant differences in treatment and varieties for all response variables, and some interactions were also significant, indicating different responses to salinity for the four varieties. Shoot, root, and total DW decreased with increasing salinity for all varieties. Visual score was highest in Autumn Joy and Blue Spruce when treated with EC5 and EC10 and lowest in Angelina and Blue Daze, the latter of which showed symptoms of moderate foliar damage including leaf necrosis, or "burn", due to salt stress. The concentrations of $\mathrm{Na}^{+}$and $\mathrm{Cl}^{-}$in the shoot tissue increased with increasing salinity while $\mathrm{K}^{+}$ and $\mathrm{Ca}^{2+}$ and the $\mathrm{K}^{+} / \mathrm{Na}^{+}$ratio tended to decrease. Of the four varieties of herbaceous perennial ornamentals evaluated in this study, Autumn Joy and Blue Spruce were considered the most relatively salt tolerant while Angelina and Blue Daze were least tolerant.
\end{abstract}

Keywords: ornamentals; herbaceous; perennials; salt tolerance; salinity

\section{Introduction}

Water is increasingly becoming the most important resource in the world today as population and urbanization increase. Not only is water essential for all life, it impacts nearly every aspect of society, including food production, human health, and even ecological health [1,2]. Because fresh water sources are limited, the use of alternative water sources, such as recycled wastewater, is important for sustainable water management [3,4]. Moreover, recycled wastewater is considered a viable and sustainable option for urban landscaping, especially in arid and semi-arid regions [5,6]. However, recycled wastewater contains elevated salt levels and harmful ions, such as sodium and chloride, which are detrimental to plant growth and aesthetic quality of many ornamental plants [7-9]. Therefore, there is a need to identify salt tolerant ornamentals that can be irrigated with alternative water sources, such as saline recycled wastewater. Selecting for and improving salt tolerance has long been pursued for agricultural crops [10], but less attention has been devoted to evaluating salt tolerance in ornamental plants [11].

Salts, primarily sodium and chloride, can impose two types of stress on plants: osmotic and ionic [12]. Osmotic stress occurs when salts accumulate in the soil near the root zone causing a reduction in water potential which impairs the plant's ability to uptake water. Plants rapidly respond 
to osmotic stress in a cascade of physiological alterations, including reduced stomatal conductance, transpiration, photosynthesis, and ultimately reduced growth [13]. Ionic stress occurs when sodium and chloride accumulate in the shoots to toxic levels where they can disrupt cytosolic metabolism leading to tissue damage [14]. This specific ion damage manifests in the leaves as chlorosis, followed by necrosis and eventually defoliation [15]. This foliar damage, or "burn", is especially a concern for ornamental plants because of its detrimental impact on aesthetic quality [16].

The Crassulaceae family, also known as stonecrops, includes the genus Sedum, which have fleshy, succulent leaves and typically yellow, pink, or red flowers that bloom in the summer [17]. Many species of Sedum are low-growing and have been used as ground cover in rock gardens and green roofs. Monterusso et al. [18] researched nine species of Sedum and found them suitable for green roofs in Michigan because of their ability to tolerate cold and drought. Sedum spp. have been shown to use Crassulacean acid metabolism (CAM) which allows the plant to open stomata at night instead of during the day to reduce water loss through transpiration [19]. Convolvulaceae, also known as the morning glory family, includes the genus Evolvulus which are herbaceous perennials. A popular ornamental, E. glomeratus ('Blue Daze') produces vibrant blue flowers and is also considered a good candidate for green roofs [20,21]. However, little is known about the salt tolerance of both Sedum spp. and E. glomeratus. Here in this study, we evaluated the salt tolerance of four herbaceous perennial ornamentals, including three varieties of Sedum and one variety of Evolvulus.

\section{Materials and Methods}

\subsection{Plant Materials and Culture}

Four varieties of perennial ornamentals were selected for this study: 'Angelina' (S. rupestre), 'Autumn Joy' (S. telephium), 'Blue Spruce' (S. reflexum), and 'Blue Daze' (E. glomeratus). Rooted cuttings were donated by Southwest Perennials (Dallas, TX, USA). The cuttings were transplanted to 6-in pots filled with Metro Mix 360 potting substrate (Sungro, Agawam, MA, USA). Fifteen days after transplanting, Marathon 1\% granular (OHP Inc., Mainland, PA, USA), a systemic insecticide, was applied as a top dressing to the substrate at a rate of 2 grams per pot as a preventative measure against any potential pests.

\subsection{Treatments and Irrigation}

A total of three treatments were used, including two saline solutions and a control. The control was a nutrient solution prepared with reverse osmosis (RO) water and Peter's Excel 15-5-15 (JR Peters Inc., Allentown, PA, USA) at a rate of $200 \mathrm{ppm} \mathrm{N}$. The electrical conductivity (EC) of the control solution was $1.5 \mathrm{mS} / \mathrm{cm}$ and the $\mathrm{pH}$ was 6.5 . The two saline solutions, referred to as EC5 and EC10, were prepared in the same manner as the control with the addition of $\mathrm{NaCl}$ to increase the $\mathrm{EC}$ to 5.0 and $10.0 \mathrm{mS} / \mathrm{cm}$, respectively. These saline solutions represent moderate and high levels of salinity that exceed the tolerance threshold of most plants [22]. The treatments were initiated 29 days after transplanting for a duration of eight weeks and applied over-head on an as-needed basis. Each plant received $1 \mathrm{~L}$ of treatment solution per irrigation which provided an approximate $30 \%$ leaching fraction to minimize the accumulation of salts in the substrate while also minimizing waste of the treatment solutions.

\subsection{Greenhouse Environmental Conditions}

The experiment was conducted in a temperature-controlled greenhouse located at Texas A\&M AgriLife Research Center in El Paso, Texas. Throughout the experiment, average day/night air temperature was $28^{\circ} \mathrm{C} / 19^{\circ} \mathrm{C}$ and the average relative humidity ranged from 17 to $46 \%$. The average daily photosynthetic photon flux density (PPFD) was $450 \mu \mathrm{mol} / \mathrm{m}^{2} / \mathrm{s}$ and the maximum was $1021 \mu \mathrm{mol} / \mathrm{m}^{2} / \mathrm{s}$. 


\subsection{Visual Quality and Leachate}

The visual quality of the foliage was assessed for damage caused by the saline treatments, including leaf burn and defoliation, and plants were scored on a scale of $1-5$, where $1=$ severe leaf burn and defoliation; 2 = moderately-severe leaf burn and defoliation; $3=$ moderate leaf burn, $4=$ minimal leaf burn; and $5=$ no leaf burn. Increments of 0.5 were used to improve the assessment for plants that were difficult to score. Here, a final rating of 1-2 is considered sensitive to salinity, 3 is considered moderately sensitive to salinity, and $4-5$ is considered tolerant to salinity. Visual score was recorded weekly throughout the experiment. Leachate was also collected weekly according to the pour-through method [23] from six random plants per treatment and the leachate EC was recorded.

\subsection{Growth Measurements}

At the termination of the study, which was eight weeks after treatment initiation, shoots were separated from roots at the substrate level and the roots were gently shaken to remove the substrate, rinsed in $\mathrm{RO}$ water, and blotted dry. All tissue samples were brought to complete dryness in a forced-air oven at $60^{\circ} \mathrm{C}$ and then dry weight was recorded. Due to the varying growth habits of the four varieties, comparisons were made using the relative values of shoot, root, and total dry weight (DW). Relative values were calculated as follows:

$$
\left(\mathrm{y}_{\mathrm{i}, \text { salt }} / \mathrm{y}_{\text {control }}\right) \times 100
$$

\subsection{Tissue Mineral Analysis}

Tissue samples were ground in a Wiley mill (Thomas Scientific, Swedesboro, NH, USA) to pass a 40-mesh screen and the dry powder samples were used for analysis The samples were digested with nitric acid and then analyzed for $\mathrm{Na}^{+}, \mathrm{K}^{+}$, and $\mathrm{Ca}^{2+}$ content using inductively coupled plasma (ICP) optical emission spectrometry [24,25]. Chloride content was determined using a $\%$ acetic acid extraction [26] and a M926 Chloride Analyzer (Cole Parmer Instrument Company, Vernon Hills, IL, USA).

\subsection{Experimental Design and Statistical Analysis}

A total of three treatments, four varieties, and six replications $(n=72)$ were randomized and all data were analyzed as a two-way analysis of variance (ANOVA) at $\alpha=0.05$ using JMP 14.2 (SAS Inc., Cary, NC, USA). Means were separated using Tukey's Honest Significant Difference (HSD) test at $\alpha=0.05$.

\section{Results}

\subsection{Leachate}

The mean leachate EC throughout the experiment of control, EC5, and EC10 treatments was 2.7, 7.3 , and $12.8 \mathrm{mS} / \mathrm{cm}$, respectively (Figure 1). The leachate EC was relatively constant in the control but varied in the EC5 and EC10 treatments. For the EC5 treatment, the leachate EC increased up to $8.0 \mathrm{mS} / \mathrm{cm}$ by the final week of the experiment. For the EC10 treatment, the leachate EC fluctuated from $15.4 \mathrm{mS} / \mathrm{cm}$ at week four to $12.9 \mathrm{mS} / \mathrm{cm}$ at week eight.

\subsection{Relative Tissue DW}

There were significant effects of treatment and varieties, but not their interactions, for relative shoot, root, and total DW (Table 1). The relative tissue DW of all four varieties decreased with increasing salinity compared to the control (Table 2). Shoot growth appeared to be more sensitive than root growth only in Angelina and Blue Daze when treated with EC5. Relative shoot DW was highest in Blue Daze and lowest in Angelina and Blue Spruce. The relative shoot DW of Autumn Joy was not significantly different from the other varieties, indicating high variability of shoot growth in response to the EC5 treatment. The relative root DW was highest in Blue Daze and lowest in Angelina, Autumn 
Joy, and Blue Spruce. The relative total DW was most reflective of shoot growth in that Blue Daze had the highest, Angelina and Blue Spruce had the lowest, and Autumn Joy was not significantly different from the other varieties. For plants treated with EC10, relative shoot, root, and total DW was highest in Blue Daze and lowest for Angelina, Autumn Joy, and Blue Spruce.

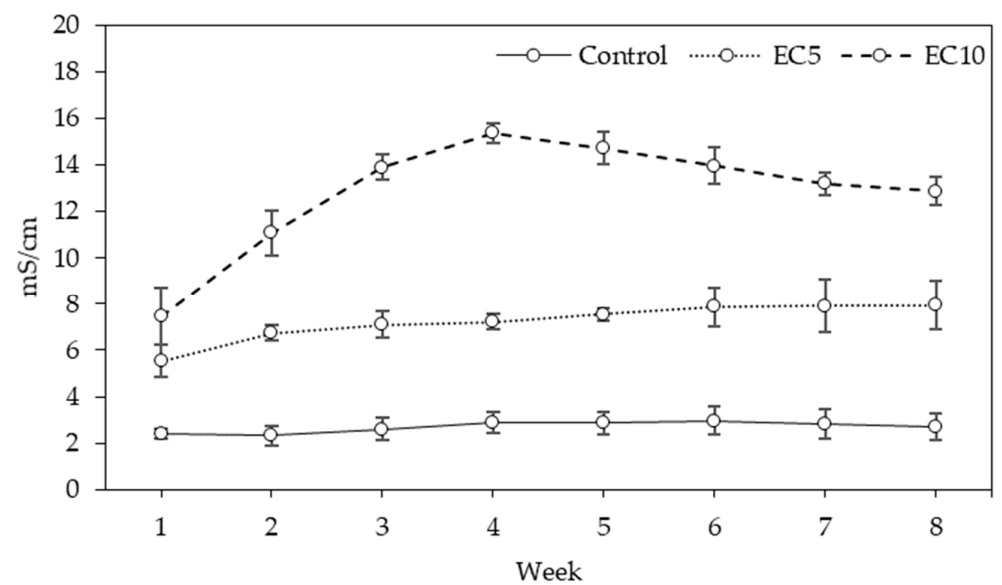

Figure 1. Mean electrical conductivity (EC) of leachate throughout the experiment. Six random containers per treatment were measured on a weekly basis. Bars represent standard deviation.

Table 1. Analysis of Variance (ANOVA) summary of all response variables measured from four varieties of perennial ornamentals irrigated with control or saline solutions for eight weeks.

\begin{tabular}{cccccccccccc}
\hline Source & $\begin{array}{c}\text { Relative } \\
\text { Shoot } \\
\text { DW }\end{array}$ & $\begin{array}{c}\text { Relative } \\
\text { Root } \\
\text { DW }\end{array}$ & $\begin{array}{c}\text { Relative } \\
\text { Total } \\
\text { DW }\end{array}$ & $\begin{array}{c}\text { Visual } \\
\text { Score }\end{array}$ & $\mathbf{N a}^{+}$ & $\mathbf{C l}^{-}$ & $\mathbf{C a}^{2+}$ & $\begin{array}{c}\mathbf{K}^{+} \\
\mathbf{K}^{+} / \mathbf{N a}^{+} \\
\mathbf{R a t i o}^{+}\end{array}$ \\
\hline Model & $<0.0001 *$ & $<0.0001$ & $<0.0001$ & $<0.0001$ & $<0.0001$ & $<0.0001$ & $<0.0001$ & $<0.0001$ & $<0.0001$ \\
Treatment & $<0.0001$ & $<0.0001$ & $<0.0001$ & $<0.0001$ & $<0.0001$ & $<0.0001$ & $<0.0001$ & $<0.0001$ & $<0.0001$ \\
Variety & $<0.0001$ & $<0.0001$ & $<0.0001$ & $<0.0001$ & $<0.0001$ & $<0.0001$ & $<0.0001$ & $<0.0001$ & $<0.0001$ \\
Treatment x Variety & 0.2455 & 0.8780 & 0.2191 & $<0.0001$ & $<0.0001$ & $<0.0001$ & 00.0057 & $<0.0001$ & $<0.0001$ \\
\hline
\end{tabular}

* Significance levels of ANOVA.

Table 2. Relative means of shoot, root, and total dry weight (DW) of four varieties of perennial ornamentals irrigated with control or saline solutions for eight weeks.

\begin{tabular}{|c|c|c|c|c|}
\hline \multirow[t]{2}{*}{ Varieties } & \multicolumn{2}{|c|}{ EC5 } & \multicolumn{2}{|c|}{ EC10 } \\
\hline & \multicolumn{4}{|c|}{ Relative shoot DW (\%) } \\
\hline Angelina & 37.29 & $\mathrm{Ba}^{\mathrm{z}}$ & 19.85 & $\mathrm{Bb}$ \\
\hline Autumn Joy & 53.28 & $\mathrm{AB}$ a & 15.70 & $\mathrm{Bb}$ \\
\hline Blue Daze & 72.47 & $\mathrm{~A} \mathrm{a}$ & 42.42 & $\mathrm{Ab}$ \\
\hline \multirow[t]{2}{*}{ Blue Spruce } & 43.93 & $\mathrm{~B} \mathrm{a}$ & 20.30 & $\mathrm{Bb}$ \\
\hline & \multicolumn{4}{|c|}{ Relative root DW (\%) } \\
\hline Angelina & 57.94 & $\mathrm{~B} \mathrm{a}$ & 19.19 & $\mathrm{Bb}$ \\
\hline Autumn Joy & 53.78 & $\mathrm{~B} \mathrm{a}$ & 14.69 & $\mathrm{Bb}$ \\
\hline Blue Daze & 91.46 & $\mathrm{~A} \mathrm{a}$ & 57.93 & $\mathrm{Ab}$ \\
\hline \multirow[t]{2}{*}{ Blue Spruce } & 47.89 & $\mathrm{~B} \mathrm{a}$ & 14.06 & $\mathrm{Bb}$ \\
\hline & \multicolumn{4}{|c|}{ Relative total DW (\%) } \\
\hline Angelina & 38.44 & $\mathrm{~B} \mathrm{a}$ & 19.81 & $\mathrm{Bb}$ \\
\hline Autumn Joy & 53.42 & $\mathrm{AB} a$ & 15.40 & $\mathrm{Bb}$ \\
\hline Blue Daze & 74.92 & $\mathrm{~A} \mathrm{a}$ & 44.42 & $\mathrm{Ab}$ \\
\hline Blue Spruce & 44.12 & $\mathrm{~B} \mathrm{a}$ & 19.88 & $\mathrm{Bb}$ \\
\hline
\end{tabular}

${ }^{\mathrm{z}}$ Means followed by different letters indicate a significant difference according to Tukey's HSD test $(p<0.05)$; uppercase letters among varieties (within columns) and lowercase letters among treatments (within rows). 


\subsection{Visual Score}

There were significant effects of treatment and varieties, including their interaction, for visual score (Table 1). The interaction indicated different responses in visual quality of the four varieties to the salt treatments (Figure 2). In general, the salt treatments reduced the visual score in all varieties except Autumn Joy (Figure 3). For the control plants, there were no significant variety differences in visual score. For plants treated with EC5, Autumn Joy and Blue Spruce had the highest visual score (5.00 and 4.83, respectively) and Angelina and Blue Daze had the lowest (4.33 and 4.17, respectively). For plants treated with EC10, Autumn Joy had the highest visual score (4.75), followed by Blue Spruce (4.08), while Angelina, and Blue Daze had the lowest (3.58 and 3.25, respectively). Declines in visual score were observed as early as week four when treated with EC5 and week three when treated with EC10.

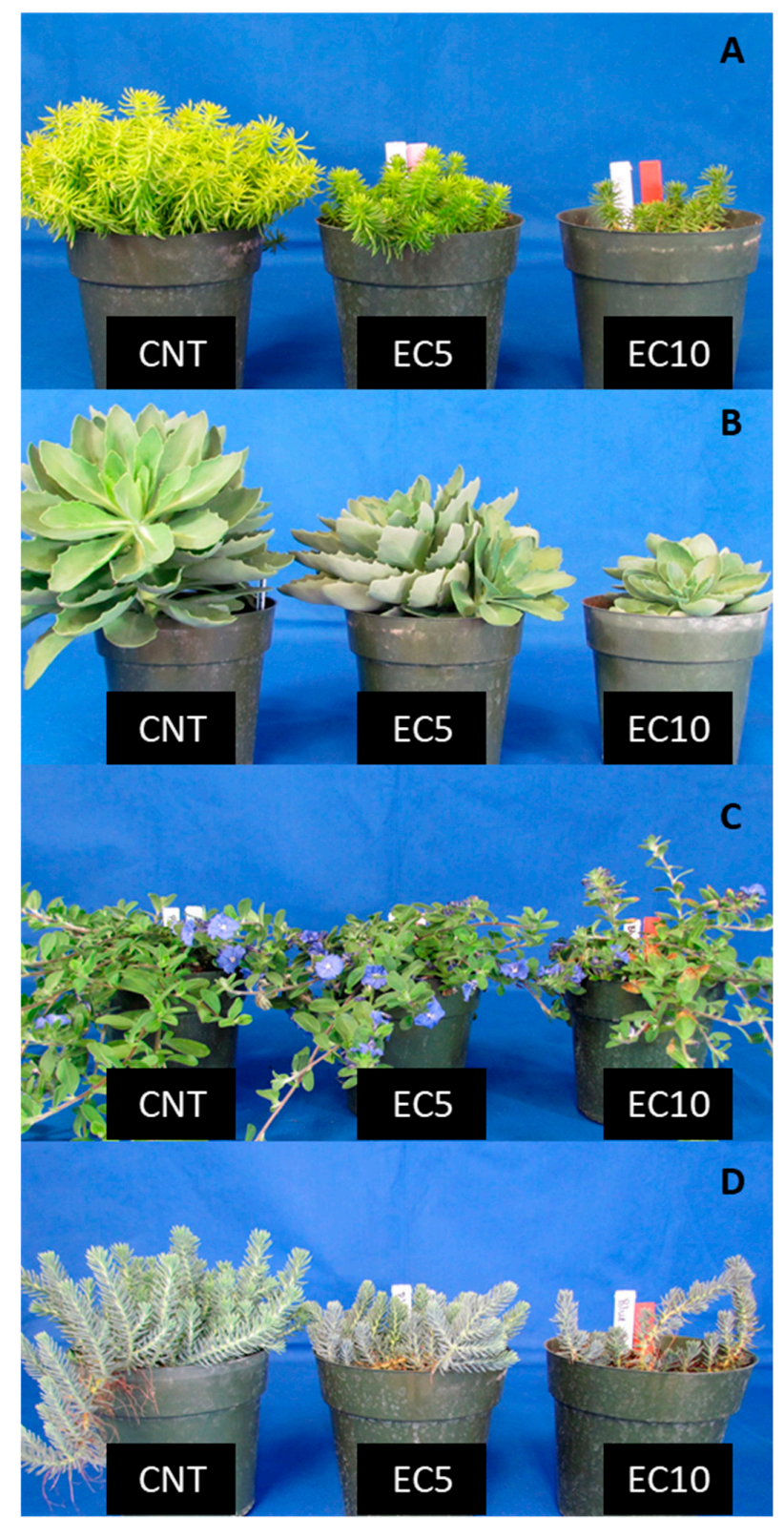

Figure 2. Representative photos of the four varieties of perennial ornamentals (Angelina (A), Autumn Joy (B), Blue Daze (C), and Blue Spruce (D)) irrigated with control (CNT) or saline solutions for eight weeks. Photos were taken at termination of the experiment. 

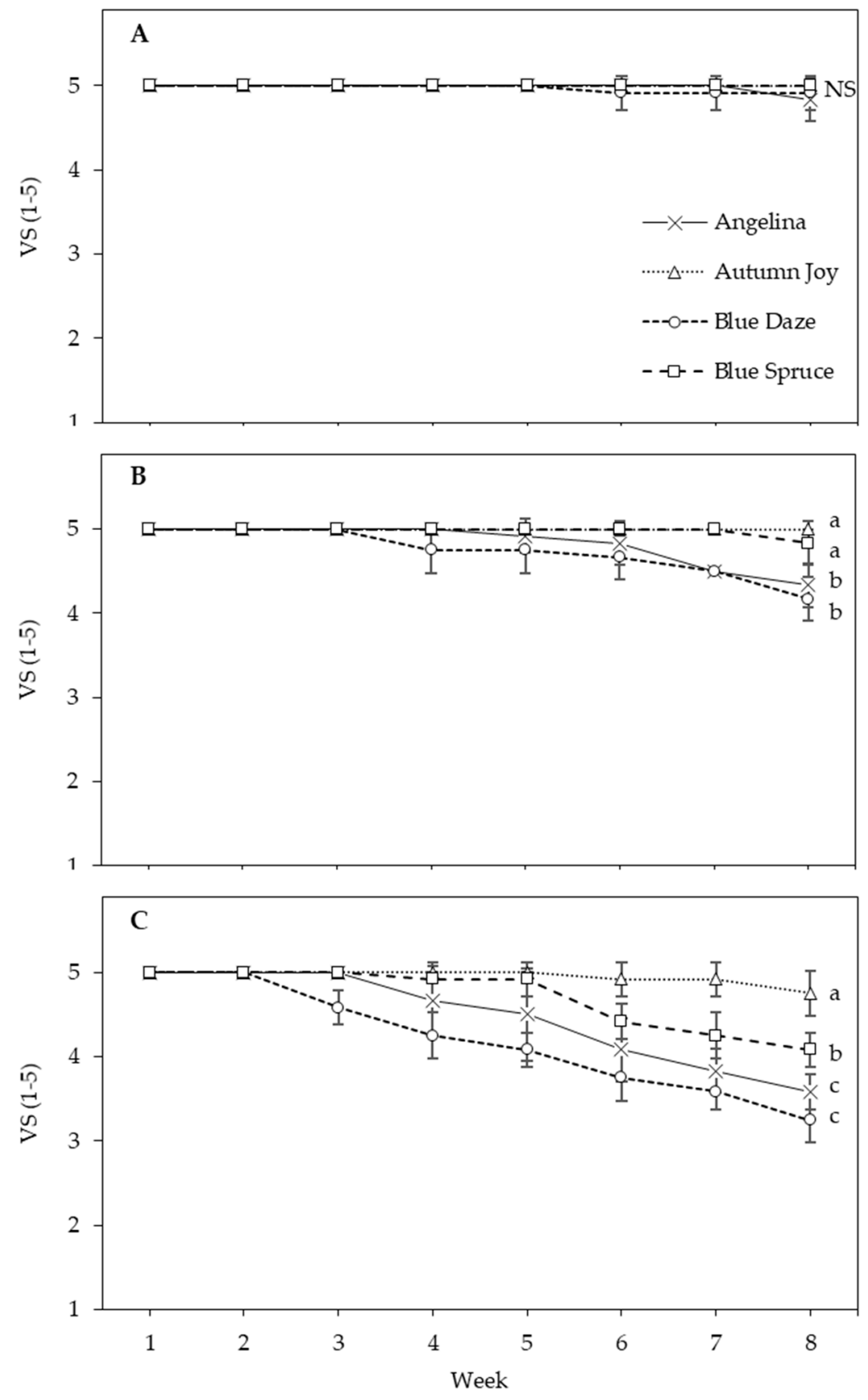

Figure 3. Mean visual score of foliar salt damage of four perennial ornamentals irrigated with control (A), EC5 (B), and EC10 (C) treatments for eight weeks. The visual score was based on a scale of 1-5, where 1 = severe leaf burn and defoliation; $2=$ moderately-severe leaf burn and defoliation; $3=$ moderate leaf burn; $4=$ minimal leaf burn; $5=$ no leaf burn. Letters indicate significant differences among varieties for the final week according to Tukey's HSD test $(p<0.05)$. Bars represent standard deviation.

\subsection{Ion Concentrations}

There were significant effects for treatment and varieties, including their interactions, for $\mathrm{Na}^{+}, \mathrm{Cl}^{-}$, $\mathrm{Ca}^{2+}$, and $\mathrm{K}^{+}$concentrations in the shoot tissue and also the $\mathrm{K}^{+} / \mathrm{Na}^{+}$ratio (Table 1 ). The interactions indicated different responses in ion concentrations of the four varieties to the salt treatments. Overall, the concentrations of $\mathrm{Na}^{+}$and $\mathrm{Cl}^{-}$in the shoot tissue increased with increasing salinity while $\mathrm{Ca}^{2+}$ and $\mathrm{K}^{+}$tended to decrease (Table 3). The $\mathrm{K}^{+} / \mathrm{Na}^{+}$ratio decreased in the salt treatments compared to the control. Autumn Joy had the lowest concentrations of $\mathrm{Na}^{+}$in the shoot tissue and the highest $\mathrm{K}^{+} / \mathrm{Na}^{+}$ratio. Blue Daze had the lowest concentrations of $\mathrm{Cl}^{-}, \mathrm{K}^{+}$, and $\mathrm{Ca}^{2+}$ and the lowest $\mathrm{K}^{+} / \mathrm{Na}^{+}$ 
ratio. Numerically, Angelina had the highest concentrations of $\mathrm{Na}^{+}$and $\mathrm{Cl}^{-}$in the shoot tissue when treated with EC10. Overall, the concentrations of $\mathrm{Na}^{+}$in the shoot tissue were lower than those of $\mathrm{Cl}^{-}$, for all treatments.

Table 3. Mean concentrations of $\mathrm{Na}^{+}, \mathrm{Cl}^{-}, \mathrm{Ca}^{2+}$, and $\mathrm{K}^{+}$, and the $\mathrm{K}^{+} / \mathrm{Na}^{+}$ratio in the shoot tissue of four varieties of perennial ornamentals irrigated with control or saline solutions for eight weeks.

\begin{tabular}{|c|c|c|c|c|c|c|}
\hline \multirow{3}{*}{$\begin{array}{l}\text { Varieties } \\
\text { Angelina }\end{array}$} & \multicolumn{2}{|c|}{ Control } & \multicolumn{2}{|c|}{ EC5 } & \multicolumn{2}{|c|}{ EC10 } \\
\hline & \multicolumn{6}{|c|}{$\mathrm{Na}^{+}(\mathrm{mg} / \mathrm{g})$} \\
\hline & 0.19 & $B c^{*}$ & 11.25 & $\mathrm{AB} b$ & 35.78 & $\mathrm{~A} \mathrm{a}$ \\
\hline Autumn Joy & 0.19 & $\mathrm{~B} \mathrm{c}$ & 7.96 & $\mathrm{Cb}$ & 16.35 & $\mathrm{Ca}$ \\
\hline Blue Daze & 0.46 & A c & 13.53 & $\mathrm{Ab}$ & 26.38 & $\mathrm{~B} \mathrm{a}$ \\
\hline \multirow[t]{2}{*}{ Blue Spruce } & 0.16 & $\mathrm{~B} \mathrm{C}$ & 9.23 & $\mathrm{BC} b$ & 32.15 & $\mathrm{AB} \mathrm{a}$ \\
\hline & \multicolumn{6}{|c|}{$\mathrm{Cl}^{-}(\mathrm{mg} / \mathrm{g})$} \\
\hline Angelina & 2.70 & $\mathrm{Ac}$ & 34.49 & $\mathrm{Ab}$ & 56.57 & $\mathrm{~A} \mathrm{a}$ \\
\hline Autumn Joy & 1.56 & $\mathrm{~B} \mathrm{C}$ & 24.60 & $\mathrm{~B} \mathrm{~b}$ & 46.49 & $\mathrm{~A} \mathrm{a}$ \\
\hline Blue Daze & 0.86 & $\mathrm{Cc}$ & 10.58 & $\mathrm{Cb}$ & 26.85 & $\mathrm{~B} \mathrm{a}$ \\
\hline \multirow[t]{2}{*}{ Blue Spruce } & 2.71 & A c & 24.79 & $\mathrm{~B} \mathrm{~b}$ & 52.01 & $\mathrm{~A} \mathrm{a}$ \\
\hline & \multicolumn{6}{|c|}{$\mathrm{Ca}^{2+}(\mathrm{mg} / \mathrm{g})$} \\
\hline Angelina & 49.90 & $\mathrm{~A} \mathrm{a}$ & 41.29 & $\mathrm{Ab}$ & 42.91 & $\mathrm{Ab}$ \\
\hline Autumn Joy & 45.94 & $\mathrm{~A} \mathrm{a}$ & 43.87 & $\mathrm{~A} \mathrm{ab}$ & 38.05 & $\mathrm{~B} \mathrm{~b}$ \\
\hline Blue Daze & 14.01 & $\mathrm{Ca}$ & 10.78 & $\mathrm{Cb}$ & 8.82 & $\mathrm{Db}$ \\
\hline \multirow[t]{2}{*}{ Blue Spruce } & 33.29 & $\mathrm{~B}$ a & 32.18 & $\mathrm{~B}$ a & 32.19 & $\mathrm{Ca}$ \\
\hline & \multicolumn{6}{|c|}{$\mathrm{K}^{+}(\mathrm{mg} / \mathrm{g})$} \\
\hline Angelina & 46.39 & $\mathrm{~B} \mathrm{a}$ & 41.34 & $\mathrm{~B} \mathrm{~b}$ & 35.49 & $\mathrm{~B} \mathrm{C}$ \\
\hline Autumn Joy & 56.65 & $\mathrm{~A} \mathrm{a}$ & 53.38 & $\mathrm{~A} a b$ & 48.26 & $\mathrm{Ab}$ \\
\hline Blue Daze & 33.20 & $\mathrm{D} \mathrm{a}$ & 19.07 & $\mathrm{Cb}$ & 13.53 & $\mathrm{Cc}$ \\
\hline \multirow[t]{2}{*}{ Blue Spruce } & 38.97 & $\mathrm{Ca}$ & 36.79 & $\mathrm{~B} \mathrm{a}$ & 32.34 & $\mathrm{~B} \mathrm{~b}$ \\
\hline & \multicolumn{6}{|c|}{$\mathrm{K}^{+} / \mathrm{Na}^{+}$ratio } \\
\hline Angelina & 279.23 & $\mathrm{~A} \mathrm{a}$ & 3.73 & $\mathrm{~B} \mathrm{~b}$ & 1.02 & $\mathrm{~B} \mathrm{~b}$ \\
\hline Autumn Joy & 304.20 & $\mathrm{~A} \mathrm{a}$ & 6.75 & $\mathrm{Ab}$ & 2.99 & $\mathrm{Ab}$ \\
\hline Blue Daze & 73.91 & $\mathrm{~B}$ a & 1.42 & $\mathrm{Cb}$ & 0.52 & $\mathrm{Cb}$ \\
\hline Blue Spruce & 262.03 & $\mathrm{~A} \mathrm{a}$ & 4.19 & $\mathrm{~B} \mathrm{~b}$ & 1.01 & $\mathrm{~B} \mathrm{~b}$ \\
\hline
\end{tabular}

* Means followed by different letters indicate a significant difference according to Tukey's HSD test $(p<0.05)$; uppercase letters among varieties (within ions and columns) and lowercase letters among treatments (within rows).

\section{Discussion}

\subsection{Leachate}

The leachate EC of the salt treatments tended to increase throughout the duration of the experiment indicating that salinity was increasing in the potting substrate and was representative of the dynamic nature of salinity. Salts can accumulate due to constant influx (e.g., irrigation) and insufficient outflux (i.e., leaching). Under natural field conditions, concentration of salts in the soil can also vary by means of evaporation, irrigation water, rising water tables, and rainfall [12,27].

\subsection{Plant Growth}

All four varieties showed reduced growth in response to salinity but no mortality was recorded throughout this experiment. Suppression of growth is the initial and most obvious response to the stress imposed on plants by salinity and can even lead to plant death [28]. For landscaping, reduced growth that does not lead to mortality of the plant can potentially be beneficial by limiting excessive growth and reducing upkeep. Shoot and root growth appeared to be similarly affected by salinity except in Angelina and Blue Daze when treated with EC5. The EC10 treatment showed similar relative 
reductions in both shoot and root growth for all varieties, even though shoot tissue is generally considered to be more sensitive to salinity than root tissue [12]. Overall, the reductions in relative total DW between Blue Daze (E. glomeratus) and the three varieties of Sedum spp. indicated some variation in salt tolerance between the genera.

\subsection{Visual Quality}

For agricultural crops, yield is considered the most important trait for salt tolerance. However, for ornamental plants, aesthetic quality is the most important trait [16]. Therefore evaluating ornamentals for salt tolerance based on visual quality is practical [7]. In this study, symptoms of foliar damage were observed in the form of leaf necrosis and ranged from minimal to moderate. This was likely due to ion toxicity from the high concentrations of $\mathrm{Na}^{+}$and $\mathrm{Cl}^{-}$in the shoots. However, the foliar damage was not severe enough to cause defoliation in any of the plants throughout this experiment. No foliar damage was observed in Autumn Joy and only minimal foliar damage was observed in Blue Spruce, Angelina, and Blue Daze when treated with EC5. When treated with EC10, minimal foliar damage was observed in Autumn Joy and Blue Spruce, while moderate foliar damage was observed in Angelina and Blue Daze. Based on these findings, Autumn Joy and Blue Spruce were considered relatively salt tolerant and Angelina and Blue Daze were less tolerant.

\subsection{Ion Concentrations}

The lower $\mathrm{Na}^{+}$concentrations that were observed in Autumn Joy indicate mechanisms for exclusion of $\mathrm{Na}^{+}$from the shoot tissue and possible retention in the root tissue, although this could not be confirmed in this study. An important feature of salt tolerant halophytes is the ability to withstand high concentrations of $\mathrm{Na}^{+}$in the shoot tissue where it is effectively compartmentalized in the vacuoles of cells $[12,14]$. However, Autumn Joy also had the highest concentrations of $\mathrm{K}^{+}$in the shoots and subsequently the highest $\mathrm{K}^{+} / \mathrm{Na}^{+}$ratio compared to the other three varieties. The maintenance of high $\mathrm{K}^{+}$in the shoot tissue is important for osmotic adjustment and is a component of salt tolerance [12,29]. Conversely, Autumn Joy had high concentrations of $\mathrm{Cl}^{-}$in the shoot tissue. Even though $\mathrm{Cl}^{-}$is an essential macronutrient in plants, it can be toxic in the shoot tissue at concentrations ranging as low as 4-7 mg/g [30]. For $\mathrm{Ca}^{2+}$, the decrease in concentrations in the shoot tissue that were observed in the salt-treated plants agrees with reports that sodium can displace calcium in the cell wall and plasma membrane of plants [29,31]. Blue Spruce had high concentrations of both $\mathrm{Na}^{+}$and $\mathrm{Cl}^{-}$along with minimal foliar damage when treated with EC10 and indicates that this species was able to effectively sequester and tolerate these high concentrations in the shoot tissue. In contrast, the moderate foliar damage that was observed in Angelina and Blue Daze was likely due to cytosolic damage from these ions.

\section{Conclusions}

Salt tolerance in plants is a surprisingly complex trait and has garnered the attention of much research over many decades. In this study, we evaluated the relative salt tolerance of four varieties of herbaceous perennial ornamentals, three Sedum spp. and one Evolvulus species. Variation in relative salt tolerance was observed in the response variables measured among genera and species. Overall, Autumn Joy (S. telephium) and Blue Spruce (S. reflexum) showed salt tolerant traits, including the ability to tolerate high concentrations of $\mathrm{Na}^{+}$and/or $\mathrm{Cl}^{-}$in the shoot tissue while maintaining good aesthetic quality with minimal damage observed in the shoot tissue.

Author Contributions: Conceptualization, G.N.; Data curation, T.H.; Formal analysis, T.H.; Funding acquisition, G.N.; Investigation, T.H.; Methodology, T.H.; Project administration, G.N.; Writing—original draft, T.H.; Writing-review \& editing, G.N.

Funding: This research was partially funded by the Agriculture Research Service (ARS) Floriculture and Nursery Research Initiative (FNRI) and the USDA National Institute of Food and Agriculture Hatch Project TEX090450. 
Acknowledgments: The authors thank Southwest Perennials, Inc. for donating plant materials for this study.

Conflicts of Interest: The authors declare no conflict of interest.

\section{References}

1. Cook, C.; Bakker, K. Water Security: Debating an Emerging Paradigm. Glob. Environ. Chang. 2012, $22,94-102$. [CrossRef]

2. Godfray, H.C.J.; Robinson, S.; Toulmin, C.; Muir, J.F.; Pretty, J.; Haddad, L.; Thomas, S.M.; Lawrence, D.; Beddington, J.R.; Crute, I.R. Food Security: The Challenge of Feeding 9 Billion People. Science 2010, 327, 812-818. [CrossRef] [PubMed]

3. EPA. Guidelines for Water Reuse; EPA: Washington, DC, USA, 2012; EPA16251R-921004.

4. Toze, S. Practicalities of Using Recycled Water. CAB Rev. Perspect. Agric. Vet. Sci. Nutr. Nat. Resour. $2008,3$. [CrossRef]

5. Carter, C.T.; Grieve, C.M.; Poss, J.A.; Suarez, D.L. Production and Ion Uptake of Celosia Argentea Irrigated with Saline Wastewaters. Sci. Hortic. 2005, 106, 381-394. [CrossRef]

6. Cassaniti, C.; Leonardi, C.; Flowers, T.J. The Effects of Sodium Chloride on Ornamental Shrubs. Sci. Hortic. 2009, 122, 586-593. [CrossRef]

7. Niu, G.; Cabrera, R.I. Growth and Physiological Responses of Landscape Plants to Saline Water Irrigation: A Review. HortScience 2010, 45, 1605-1609. [CrossRef]

8. Wu, S.; Sun, Y.; Niu, G.; Lizette, G.; Pantoja, G.; Rocha, A.C. Responses of Six Lamiaceae Landscape Species to Saline Water Irrigation. J. Environ. Hortic. 2016, 34, 30-35.

9. Zollinger, N.; Koenig, R.; Cerny-Koenig, T.; Kjelgren, R. Relative Salinity Tolerance of Intermountain Western United States Native Herbaceous Perennials. HortScience 2007, 42, 529-534. [CrossRef]

10. Flowers, T.J. Improving Crop Salt Tolerance. J. Exp. Bot. 2004, 55, 307-319. [CrossRef] [PubMed]

11. Abad, M.; Carrión, C.; García-Agustín, P.; Noguera, V.; Fornes, F.; Belda, R.M. Pre-Conditioning Ornamental Plants to Drought by Means of Saline Water Irrigation as Related to Salinity Tolerance. Sci. Hortic. 2007, 113, 52-59. [CrossRef]

12. Munns, R.; Tester, M. Mechanisms of Salinity Tolerance. Annu. Rev. Plant Biol. 2008, 59, 651-681. [CrossRef]

13. Parida, A.K.; Das, A.B. Salt Tolerance and Salinity Effects on Plants: A Review. Ecotoxicol. Environ. Saf. 2005, 60, 324-349. [CrossRef]

14. Flowers, T.J.; Munns, R.; Colmer, T.D. Sodium Chloride Toxicity and the Cellular Basis of Salt Tolerance in Halophytes. Ann. Bot. 2015, 115, 419-431. [CrossRef] [PubMed]

15. Ferguson, L.; Grattan, S.R. How Salinity Damages Citrus: Osmotic Effects and Specific Ion Toxicities. Horttechnology 2005, 15, 95-99. [CrossRef]

16. Bernstein, L.; Francois, L.E.; Clark, R.A. Salt Tolerance of Ornamental Shrubs and Ground Covers. Am. Soc. Hort. Sci. J. 1972, 97, 550-556.

17. Moran, R. Crassulaceae Stonecrop Family. J. Arizona-Nevada Acad. Sci. 1993, 27, 190-194.

18. Monterusso, M.A.; Bradley Rowe, D.; Rugh, C.L. Establishment and Persistence of Sedum Spp. and Native Taxa for Green Roof Applications. HortScience 2005, 40, 391-396.

19. Gravatt, D.A.; Martin, C.E.; Url, S. Comparative Ecophysiology of Five Species of Sedum (Crassulaceae) under Well-Watered and Drought-Stressed Conditions. Oecologia 1992, 92, 532-541. [CrossRef] [PubMed]

20. Ketjarun, K.; Staples, G.W.; Swangpol, S.C.; Traiperm, P. Micro-Morphological Study of Evolvulus Spp. (Convolvulaceae): The Old World Medicinal Plants. Bot. Stud. 2016, 57. [CrossRef] [PubMed]

21. Kanechi, M.; Fujiwara, S.; Shintani, N.; Suzuki, T.; Uno, Y. Performance of Herbaceous Evolvulus Pilosus on Urban Green Roof in Relation to Substrate and Irrigation. Urban For. Urban Green. 2014, 13, 184-191. [CrossRef]

22. Tanji, K.K.; Kielen, N.C. Agricultural Drainage Water Management in Arid and Semi-Arid Areas; FAO Irrigation and Drainage Paper 61; FAO: Rome, Italy, 2002.

23. Torres, A.P.; Mickelbart, M.V.; Lopez, R.G. Leachate Volume Effects on PH and Electrical Conductivity Measurements in Containers Obtained Using the Pour-through Method. Horttechnology 2010, 20, 608-611. [CrossRef]

24. Havlin, J.L.; Soltanpour, P.N. A Nitric Acid Plant Tissue Digest Method for Use with Inductively Coupled Plasma Spectrometry. Commun. Soil Sci. Plant Anal. 1980, 11, 969-980. [CrossRef] 
25. Isaac, R.A.; Johnson, W.C. Collaborative Study of Wet and Dry Ashing Techniques for the Elemental Analysis of Plant Tissue by Atomic Absorption Spectrophotometry. J. Assoc. Off. Anal. Chem. 1975, 58, 436-440.

26. Gavlak, R.G.; Horneck, D.A.; Miller, R. Plant, Soil, and Water Reference Methods for the Western Region; Western Rural Development Center: Logan, UT, USA, 1994.

27. Ayers, R.S.; Westcot, D.W. Water Quality for Agriculture; 29 Rev. 1; FAO: Rome, Italy, 1985; ISBN 92-5-102263-1.

28. Tester, M.; Davenport, R. Na ${ }^{+}$Tolerance and $\mathrm{Na}^{+}$Transport in Higher Plants. Ann. Bot. 2003, 91, 503-527. [CrossRef]

29. Zhang, J.L.; Flowers, T.J.; Wang, S.M. Mechanisms of Sodium Uptake by Roots of Higher Plants. Plant Soil 2010, 326, 45-60. [CrossRef]

30. White, P.; Broadley, M.R. Chloride in Soils and Its Uptake and Movement within the Plant: A Review. Ann. Bot. 2001, 88, 967-988. [CrossRef]

31. Essah, P.; Davenport, R.; Tester, M. Sodium Influx and Accumulation in Arabidopsis. Plant Physiol. 2003, 133, 307-318. [CrossRef]

(C) 2019 by the authors. Licensee MDPI, Basel, Switzerland. This article is an open access article distributed under the terms and conditions of the Creative Commons Attribution (CC BY) license (http://creativecommons.org/licenses/by/4.0/). 